\title{
RISKS OF REGULATION IN NETWORK INDUSTRY - CASE OF THE SLOVAK REPUBLIC
}

\section{Jozef Klučka ${ }^{1}$}

\begin{abstract}
Historically, the Slovak Republic infrastructure involved monopolies, with the State operating sectors of electricity, telecommunications, postal services, gas, and water supply through state enterprises. The electric energy sector has since become privatized in the Slovak Republic. Because of insufficient competition (oligopoly), a regulatory office formed with the role of price regulation. In this pricing area, the electricity supply sector suffered turmoil in the Slovak Republic. This paper addresses some practicalities of regulation and proposes measures to minimize risks relating to decisions of the regulating authority. The current issues reflect problems of price regulation of electricity in the Slovak Republic that have resulted in political disputes. This paper describes the regulatory framework of network industries in the Slovak Republic and general assumptions for transparent and efficient regulatory process. It includes an analysis of certain aspects of price regulation and the role and responsibilities of a chairman and other stakeholders in this process. Some measures are proposed to minimize the future risks of price regulation. These measures cover internal subjects and processes as well as the external environment involving stakeholders and their influence on negotiating prices.
\end{abstract}

JEL Classification Numbers: H25, K23; DOI: http://dx.doi.org/10.12955/cbup.v5.930

UDC Classification: 338.2

Keywords: regulation, electricity, price regulation

\section{Introduction}

Historically, sectors of infrastructure in the Slovak Republic were monopolies (electricity, telecommunications, postal services, gas, and water supply). The state was the operator of these areas through state enterprises. A trend of liberalization started the transformation of these corporations. Because of the imperfect market environment, however, these became subject to regulation. For this purpose, the Regulatory Office for Network Industries (URSO) was established to regulate prices.

In regulating prices, electricity supply suffered turmoil in the Slovak Republic, and this was accompanied with political turbulence. As a result, the chairman of the regulatory office resigned.

Liberalization is a trend promoted by European Union (EU). It originates from the assumption that markets and competitions increase the competitive position of a country and, thereafter, market prices will decline. With monopolies transforming into entities in a market economy, competition becomes active. Moreover, monopolies that transform from state enterprises to private corporations operating in a market find the market restrictive (because of various reasons). The limited competition (oligopoly) results in a regulatory office forming with an objective of monitoring privatized corporations and their market behavior.

Current problems reflect issues within the price regulation of electricity in the Slovak Republic and which have resulted in political disputes. Hence, the objective of this paper is to address some practicalities of regulation and propose measures that could minimize risks in decisions of the regulating authority.

\section{Methods}

To identify the core problems and propose measures, the study analyzed the competencies and processes within the office responsible for the regulation of network industries, the URSO. It also identified stakeholders, their objectives, and potential problems that stem from their contradictory objectives.

The problem of price regulation (expanded to include heating prices) was assessed using a systematic approach to analyzing the following processes:

- appointment of an office chairman,

- chairman communication with other stakeholders,

- professional and ethical status of a chairman,

\footnotetext{
${ }^{1}$ Faculty of Security Engineering, University of Žilina, jozef.klucka@fbi.uniza.sk
} 
- chairman's responsibility taking into account:

○ transparency of proposed or approved decisions,

- functions of regulatory council and fulfillment of control within the regulatory office.

- the requirement for explicit risk formulation related to the specific proposal of measures to minimize identified risks or the written expression to identified risks and their impacts on society and the customer segment.

\section{Regulatory Framework - Case of the Slovak Republic}

The theoretical background of regulation is straightforward: where there is no fully competitive market, there exists either an oligopoly or a monopoly. This market structure creates potential imbalances and economic and social disturbances. Therefore, regulation becomes necessary. The fundamental role of regulation (and an established regulatory body) is to build a regulatory framework. There are three theories (Shleifer, 2005) that explain economic regulation: public interest theory, contracting theory, and capture theory. Shleifer (2005, p. 446) identifies the key problem as being, "risk of public abuse of market participants by an official who is either pursuing his own political interests or is captured by a particular group, including the regulated industry itself."

Tirole (2014) declares two problems of regulation:

- many markets are dominated by a few firms that together influence the process in volume and quality, and

- a regulatory authority's lack of information about firm`s costs and the quality of goods and services it delivers.

The main objectives of regulation can be summarized as follows:

- to keep a balance between customers' and investors' interests,

- to safeguard return on investment into regulated enterprises,

- to add stimuli for the proper functioning of regulated enterprises, and

- support and format a fully competitive market environment.

The profound requirements of the effective regulatory body can be formulated as:

- independence - its solutions are based on a professional evaluation of data and based on communications with stakeholders when decisions are approved; independence is linked to nonpolitical activities in decision processes;

- professionality/expertise - decisions are strictly based on documented data and empirical evidence; the framework is limited to the bill (Nr. 250/2012 Coll.);

- openness - activities of the regulatory body, where decisions are published and monitored by public control; and

- control/evaluation - decisions of the URSO can be verified by a court, and a regulating entity has the possibility to appeal against decisions.

\section{Case of the Slovak Republic -- Price Decision on Electricity}

In January 2017, the URSO approved a price decision (price of electricity) that changed the tariffs for various categories of customers. Incorporating the growth of fixed charges into the electricity price was the reason given for a dramatic increase. The price decision was sent to distributed companies that started to print and distribute invoices with new price declarations. For many households, communities, and enterprises, the new price policy increased electricity prices by $300 \%$ (Zákazníkom, 2017; Fico, 2017).

The regulator's decision had these consequences:

- incorporating the Prime Minister into the agenda for charges relating to electricity (price decision of regulator);

- resigning of the chairman of the regulatory office following a request from representatives of the political coalition for him to resign; the government would propose to the President a new candidate for the position of chairman of the URSO;

- declaring the price decision to be invalid, and declaring a new one; the sum of advanced payments will depend on a new price decision.

The economic problem had grown into a political one. People challenged the $300 \%$ increase in charges, since unofficially the price for electricity was meant to have decreased by $10 \%$. 
A bill (Nr.250/2012 Coll.) controls the regulation of network industries in the Slovak Republic. As a member of the EU, the Slovak Republic also incorporates norms in regulating network industries within EU.

The scope of regulated activities covers several areas:

- generation, transmission, distribution, and supply of electricity;

- the performance of the short-term electricity market administrator`s activities;

- production, transport, storage, and supply of gas;

- production, distribution, and supply of heat;

- production, distribution, and supply of potable water;

- diversion and purification of the sewage system; and

- abstraction of surface water and energy water from water flows.

Transparency and non-discriminatory approaches of the regulatory body, URSO, are based on the law. Strategy and day-to-day activities are governed by a chairman and regulatory council. Regulatory Council approves strategic management of the office and concept of regulation in network industries. The head of the council is the chairman of the office. Employees are excluded from the membership in the council. Chairman of the office is appointed and recalled by the president - upon the proposal of the Government of the Slovak Republic ( $\$ 5$, sec. 1 of the Act). The President recalls the chairman after fulfillment of conditions explicitly given in the Act ( $\$ 5$, sec.11 of the Act). Conditions for recall correspond to fundamental requirements of the objective and expert and independent activity of the chairman who governs the office and is representative of the regulatory office in the business and the nonbusiness environment.

The office also deals with operational activities. The strategic document determines the framework of regulation. The council approves the strategic policy that contains the performance of price regulation for a future period. The office is obligated by law to publish information related to its decisions on their website. This requirement guarantees openness and transparency of decisions and activities of the office.

\section{Problem of Price Regulation}

The price proceeding for the regulated activities (covering a broad spectrum including electricity distribution for citizens, communities, and enterprise subjects) commences upon the initiative of the office ( $\$ 14$, sec.2 of the Act). Price regulation of the office activities imply the following requirements:

- professional competency and independence of the office;

- system approach to price decision for individual customers' segments;

- the openness of the office to professionals and the general public; and

- risk identification arising from the regulatory policy.

In all the above-mentioned, potential motives exist for a similar status to that of the past that lead to approval of a price decision with remarkable social-political problems. For this reason, future measures are recommended to minimize the risks of repeating such a price decision in the process.

\section{Appointment of an Office Chairman}

The current system is based on political nomination. The proposal is submitted by the government; each government is aware of the seriousness and complexity of the regulatory body decisions, and therefore, a nominee is appointed from political parties that create a governmental coalition. It would be useful for the appointment of such a chairman to be based on negotiations with political coalitions and professional organizations. In practice, the weight of high ranking professional authority has the same value as personal integrity. The fundamental condition of application is the willingness of political parties to cooperate and communicate with professionals and the general public.

A Comprehensive System of Communication Between a Chairman and Stakeholders

This process is officially fulfilled with all decisions (ex-post) published on the website of the office. The decision, however, requires communication during preparation and submission of a price. Each decision should follow the regulation strategy, and therefore regulatory council should be aware of such; Council in the case of identifying a discrepancy between strategy and price decision has the competency to disagree (to submit objection) towards price decision. Moreover, similar to a 
consultation exercise, the price decision should be disseminated to representatives of customers, academics, and professionals to evaluate the proposal. The consultation exercise has to be formulated as an obligatory for specified organizations, whom the price decision (proposal) will be delivered. These institutions will be the regulatory council, departments of the regulatory office, customer's, and non-profit, academic, and professional institutions.

\section{Professional and Ethical Status of a Chairman}

The scope and heterogeneity of problems place a high demand on the expertise of the chairman. It is essential to create experienced and professional staffing within the office. The prescribed standards of conduct for the chairman, high-level management, and the regulatory council need to be written as an internal norm of URSO. It is also proposed that a change in status occurs where the URSO chairman is also the chairman of the council so that the council is entirely independent of the URSO (i.e., with no personal relationships with representatives).

Chairman's Responsibility

This component pertains to the transparency of proposed decisions and functions of the regulatory council and providing a control function in processes of the regulatory authority. Regarding price decisions, the chairman communicates with departments within the office (internal communications) as well as stakeholders (external communications). Therefore, the chairman may propose, at ad hoc, the structure or platform that fulfills the dissemination of information to prepare a price decision and the risks related to such. An application of control function stresses the need for openness towards stakeholders and an obligation to evaluate the price decision before approving the regulatory policy. Where any discrepancies are found, the proposal is to be modified and communicated in the next cycle.

\section{Conclusion}

The case in the Slovak Republic for a regulatory framework dealing with the price of electricity indicates the importance and complexity of regulation. This paper addressed key fundamental preconditions for effective regulation. Based on this case, proposed activities include modifications to the current framework to minimize potential future turmoil for society. The complexity of the subject also indicates the need for transparency, independence, and a professional regulatory institution headed by a chairman.

\section{References}

Carrigan Ch., Coglianese C. (2016): Capturing Regulatory Reality: Stigler`s The Theory of Economic Regulation. Faculty Scholarship Paper 1650, University of Pennsylvania, retrieved from: scholarship.law.edu/faculty scholarship Fico ukázal, ako roztrhat' faktúru (2017). N, Bratislava retrieved from:

https://dennikn.sk/664533/fico-ukazal-ako-roztrhat-fakturu-opakuje-ze-vyssie-ceny-za-energie-neplatia/zákon https://ekonomika.sme.sk/c/20478241/zakaznikom-vse-klesnu-ceny-elektriny-v-priemere-o-235percenta.html\#ixzz4aoQqh2sw

Nr. 250/2012 on regulation in network industries. (2012) retrieved from: http://www.urso.gov.sk/sites/default/files/z_2502012_en.pdf

Organizačný poriadok (2012), URSO, retrieved from: http://www.urso.gov.sk/?q=content/\%C3\%BAradorganiza\%C4\%8Dn\%C3\%BD-poriadok\&language $=$ sk

Rochet, J-Ch., Tirole J. (2003) Platform competition in two-sided markets, European Economic Associations, retrieved from: http://www.rchss.sinica.edu.tw/cibs/pdf/RochetTirole3.pdf

Rochet, J-Ch., Tirole J.: Two-Sided Markets (2004) retrieved from: http://web.mit.edu/14.271/www/rochet_tirole.pdf

Shleifer, A. (2005). Understanding Regulation. European Financial Management vol.11, No.4, 439-451, retrieved from: http://www3.udg.edu/fcee/professors/nboccard/micro2/part2/Shleifer.pdf

Zákazníkom VSE pošlú nové faktúry so zníženou cenou .(2017), SME, Bratislava, retrieved from: 